\title{
REGRESSION ANALYSIS OF THE RELATIONSHIP BETWEEN SELECTED VARIABLES OF ECONOMIC GROWTH AND SUSTAINABLE DEVELOPMENT
}

\author{
aTIÍLIA ZORKÓCIOVÁ, 'HANA PALUŠKOVÁ, 'SONIA \\ KRAJČÍK DANIŠOVÁ \\ University of Economics in Bratislava, Dolnozemská cesta 1, \\ 85235 \\ email: ${ }^{a}$ otilia.zorkociova@euba.sk, ${ }^{b}$ hana.paluskova@euba.sk, \\ csonia.krajcik.danisova@euba.sk
}

This paper was created within the research projects of the Ministry of Education, Family and Sport of the Slovak Republic VEGA No: 1/0420/19

Abstract: Environmental threats of anthropological origin, such as global warming rising water levels, air pollution, excessive waste generation, or the seas and oceans quality decline, are threats that directly affect us. Thus, the main goal of this pacer is quality decline, are theats that directly affect us. Thus, the main goal of this paper is limits through regression current economic development in the intentions of planetary limits through regrion analysis using cross-sectional and panel data evaluating the dependence of ecological footprint per person, gross domestic product per person and Sustainable Development hdex. The analysis shows that economic development in line with the current maket rules contributes to expand the ecological footprint. We argue that boh geen measures into international and national policies as an effective monitoring of the achievement of sustainable goals of all market actors are necessary.

Keywords: regression analysis, economic growth, sustainable development, ecological footprint per person, gross domestic product per person, quality of life

\section{Introduction and Problem Formulation}

Consumption, which is prevalent today in the society of developed countries, but also in countries with a growing middle class, is often absent from aspects of sustainability that take into account the effect use of natural resources. Recent decades were characterized by rapid population growth and depletion of natural resources. This is one of the reasons why the concept of sustainable development has increasingly appeared in many social science areas (Kajikawa, 2008).

As stated by Kuznets' environmental curve, economic growth pollutes and damages the environment, but declines from a certain level. Given that global society has exceeded the level of global biocapacity, it can be argued that it is not right to wait for a hypothetical break in the future (according to Mikkelson, 2019). At the same time, the author emphasizes that economic growth depletes natural resources and pollutes the environment more than it contributes to society. However, the economist DeGrauwe, is of the opinion that so far the only systems that have created well-being for people in society have been built on market mechanisms. However, he pointed out the limits that can be understood as negative externalities of companies borne by people (In Vaňo, 2019). Cubilka and Giljum (2020) argue that sustainable growth cannot be achieved if the "boundaries" of the Earth have already been exceeded and according to the authors Holm and Englund (2009) the transition to a highly efficient information society does not lead to a reduction in the use of natural resources, as experts have predicted in the past.

According to a panel analysis by Chen and Chang (2016) conducted in 99 countries from 1981 to 2006, economic development causes an increase in the ecological footprint ${ }^{1}$. However, this effect differs from the maturity of the economy. This means that GDP per capita growth in less developed countries will affect the growth of the environmental footprint to a lesser extent than GDP per capita growth in developed market economies. Therefore, one of the authors' recommendations is that developed high-income countries should help low-income countries through technology transfer and financial incentives.

A useful and very advantageous and therefore often used benefit of GDP is that this indicator is able to include total human activity in one figure. However, the authors Majid, Zaman and Halim (2018) came to the conclusion that the ecological 1 The ecological footprint is an indicator that expresses how the individual biological also the absorption of waste as a result of human activity. footprint of a landscape is directly proportional to its economic development. They emphasize that high economic growth and reckless use of natural resources have direct negative effects on the ecological balance, resulting in a decline in the biological capacity of countries. At the same time, they note that countries with higher GDP emit more emissions and thus contribute more to global warming, precisely because of higher demand for energy consumption.

According to the latest data from the Global Footprint Network (2020), there are currently 1.7 global hectares (gha) of natural resource consumption (and waste generation) per individual, which the planet is able to restore in one year (calculated on the basis of population size) - which represents an average biocapacity of the Earth per capita. Out of the total number of 188 evaluated countries, only 58 of them reached a given or lower level, taking into account their economic activities. These countries include the least developed economies, mainly from sub-Saharan Africa, South and South-East Asia, and one transitional economy, Kyrgyzstan. OECD countries were above a sustainable level of ecological footprint per capita, ranging from 12.8 gha (Luxembourg) to 1.9 gha (Colombia).

Despite above, the OECD countries have been the best ranked in achieving the UN's sustainable development goals (Agenda $2030^{2}$ ). Almost half of them placed the first 17 places and in total belonged to the 70 best countries of this evaluation. Turkey, Mexico and Colombia ranked in the last positions within the OECD and thus significantly negatively shifted the overall position of the group of the most developed economies in the monitored indicator (UN, 2020).

European economies are among the top 15 economies ${ }^{3}$ closest to achieving the sustainable goals of the 2030 Agenda. Despite the relatively good level of education, health care and overall social conditions, they show the worst development in the areas of Responsible Consumption and Production (SDG 12) and Climate Action (SDG 13). The ecological footprint per person of these 15 economies was in the range of $7.2-4.2$ gha.

Based on the above, it can be stated that the solution of excessive consumption, which is characteristic especially for the developed countries is a fundamental and urgent issue today. Its solution requires effective management of natural resources, most ideally at the global, but certainly at least at a broad international and subsequently national level. In our opinion, one of the steps that could enable the individual economies to develop sustainable production and consumption would be constant monitoring of natural resource extraction through the ecological footprint indicator.

\section{Methodology}

A verification of the theoretical claims in the presented scientific article should be support by the application of the method of regression analysis (using cross-sectional and panel data), through which we examine the dependence of selected variables characterizing the current economic development in the conditionality of sustainable development.

In the first step, we decided to create a regression model using cross-sectional data, in which we examined the interdependence of selected variables in 26 observations. The observations represent EU countries - except Luxembourg, which we had to omit from the analysis because data of one selected indicators (SDI) were not available for this country.

2 Agenda 2030 contains of 17 sustainable development goals divided into 169 targets adopted by UN member states in 2015.

3 Sweden, Denmerk, Finland, Frow Netherlands, Estonia, Belgium, Slovenia, United Kingdom, Ireland and Switzerland 
We obtained the input data of the examined indicators from the international databases of the World Bank (WB), the Global Footprint Network and the database of the Sustainable Development Index and processed them in the Microsoft Excel program. Afterwards we evaluated the processed electro metrics data in the Gretl program.

The quantitative analysis examines the relationship between the dependent variable ecological footprint per capita and the independent variables - gross domestic product per capita (GDP per capita) and the Sustainable Development Index (SDI). The result of the regression analysis expresses to what extent (and if at all) the independent variable (in our case 2 independent variables) is related to the dependent variable.

When implementing the first model of regression analysis, the latest data were available (at the time of analysis) for the ecological footprint per person indicator for 2017, and therefore we used the data from the same year for the remaining two variables. Since the output of the regression analysis may be limited mainly in terms of the observed period ( 1 year), to verify the statistical significance of the outputs, we further apply a panel regression analysis that examines the same selected variables in EU countries (except Luxembourg) in 1995 - 2017.

The initial equation for a given analysis can be written in the form (Lukáčik - Lukáčiková - Szomolányi, 2011):



In the following section, we provide a more detailed specification of selected variables, which we inserted into the regression analysis:

Dependent variable:

a) Ecological footprint per capita (EFP per capita) - the ecological footprint is an indicator that expresses how the individual biological components of the earth (soil and water) are used for production, consumption, but also the absorption of waste due to human activity. In our model, the given indicator represents a dependent variable and expresses the efficient use of the Earth's resources in the context of sustainable development. The data was obtained from the database of the Global Footprint Network (2021) and expressed in global hectares:

Global hectare (gha) = biologically productive hectare, expressing the average world biological productivity, mostly in one year.

In our model, we have placed the ecological footprint per person, which therefore represents the share of a biologically productive hectare - expressing the average world biological productivity (usually in one year) and the size of the population of the given country.

Independent variables:

b) Gross domestic product per capita (GDP per capita) expresses the share of the sum of goods produced in the territory of a given country (mostly in one year) and the total population. The given indicator can currently be considered the most frequently used indicator of the economic level and growth of individual national economies and in our model represents the independent variable. Data for this indicator were obtained from World Bank databases (WB, 2021) and are expressed in current prices (US dollars). The given indicator can be expressed by the equation (according to Lisý et al., 2011):

$$
\frac{G D P=C+I+G+N X}{\text { population }}
$$

C - household expenditure on personal consumption of goods and services (final consumption of households);

I - a private gross domestic investment of enterprises (gross fixed capital formation); G - government expenditure on the purchase of goods and services (final consumption of government);

NX - net export, which we get when we deduct from the total volume of exports the total volume of imports for a given period of time.

c) The Sustainable Development Index (SDI) - was created to increase the informative value of the Human Development Index (HDI) by updating on the impact of human activity on the environment - with the main idea to achieve both human development and environmental sustainability (SustainabledevelopmentIndex.org, 2021). We have chosen the SDI Index as an independent variable, which in our model represents a development of society that increases the wellbeing of people and at the same time preserves natural resources at a sustainable level.

We express the result of the SDI Index on a scale of 0 to 1 , while countries approaching the score of 1 better than countries whose final score is closer to 0 . A country that would reach level 1 would have to meet all the set criteria resulting from the calculation of the indicator, thereby the development of its people would be fully in line with the principles of sustainable development. The SDI Index can be expressed using the formula (Sustainabledevelopmentindex.org, 2021 a.):

$$
S D I=\frac{\text { Development Index }}{\text { Ecological Impact Index }}
$$

The Development Index is derived from the United Nations Development Program (UNDP) using the same data set that underpins the Human Development Index (HDI) and can be expressed as follows:

Development Index $=\sqrt[s]{\text { Life Expectancy Index } \times \text { Education Index } \times \text { Income Index }}$

- The Life Expectancy Index is calculated as the ratio of the difference between life expectancy at birth (in the given country) and the number 20; and the difference between numbers 85 and 20.

- We calculate the Education Index as the ratio of the sum of years of schooling (maximum value by 2025 is set at 15 years and minimum value is 0 years) and expected years of schooling (maximum value is set at 18 years - equivalent to obtaining higher education in most countries and minimum value is 0 years) with the number 2 .

- We calculate the Income Index according to the formula:

$$
\text { Income Index }=\frac{\ln (\text { GNI per capita })-\ln (100)}{(\ln 20000)-\ln (100)}
$$

GNI - gross nations income

The Income Index differs from the HDI Index in setting limits in the scoring of individual countries. The HDI sets a point limit where the maximum value of gross national income per person may not exceed 75,000 USD, because achieving an income of 75,000 USD is empirically incompatible with the planet's borders. The Income Index in the SDI indicator differs from the HDI Index and sets a limit when the maximum value of gross national income per person is not more than 20,000 USD. This means that earning above this level no longer increases the country's score. At the same time, the difference between the limit set in the HDI Index and the SDI Index is minimal (according to the HDI Index, the country score would increase by 0.05 points above the set level of USD 20,000) and does not significantly change the relative ranking of countries, except for a few countries, which achieve better scores in the HDI Index due to (relatively) high income, despite the fact that Life Expectancy Index and Education Index are (relatively) low such as Kuwait, whose relative position in the SDI Index would fall for this reason (Sustainabledevelopmentindex.org, 2021 a.).

We calculate the Ecological Impact Index as follow: 


$$
\text { Ecological Impact Index }=1+\frac{e^{\wedge O}-e^{1}}{e^{4}-e^{1}}
$$

(if $\mathrm{AO}>4$, then $\mathrm{EII}=\mathrm{AO}-2$ )

AO represents the average exceedance of the Earth's biocapacity, according to the formula:

$$
A O=\sqrt[s]{\left(\frac{\text { Material Footprint }}{\text { planetary boundary }} \leq 1\right) *\left(\frac{\text { CO2 }}{\text { planetary boundary }} \leq 1\right)}
$$

Material footprint - is calculated from the total extraction and consumption of materials, including biomass, minerals, fossil fuels, and building materials.

$\mathrm{CO} 2$ - represents the value of produced $\mathrm{CO} 2$ emissions of the given country per year.

Planetary boundary - represents the limit when the global biocapacity of the Earth is or is not exceeded, depending on the size of the population in a given year (Sustainabledevelopmentindex.org, 2021 a.)

\section{Results}

The basic premise of the theory of sustainable development is to preserve, protect and promote the quality of life on Earth. According to data from the Global Footprint Network (2020), it is clear that a society in a resource-constrained environment is not behaving effectively in terms of the rationality of individual entities. A global society focused on economic growth, measured by GDP per capita, cannot be efficient in the long run without proper natural resource management.

To verify this statement, we chose the method of regression analysis, where we examine the relationship between selected variables: ecological footprint per capita, GDP per capita, and Sustainable Development Index (SDI) in EU countries (except Luxembourg) in 2017. We chose the EU countries because they represent a relatively homogeneous sample in terms of economic level and because their average ecological footprint per person exceeds the average global biocapacity of the Earth per capita (> 1.7 gha). Last but not least, because the Slovak Republic is also a member state of the EU.

In the applied regression analysis, we assume that one variable depends on the other. In this model, we chose the ecological footprint per person as the dependent variable, and indicators that can affect the dependent variable are GDP per capita and the SDI index. All three indicators with their selection explanation are characterized in methodology.

The relationship between the one dependent and the two independent variables is expressed in Table 1 . In order to obtain elasticities, the results of the three indicators examined were logarithmized.

Tab. 1: Regression analysis: Model 1

Model 1: OLS, using observations 1-26

Dependent variable: 1_EFP_pc_2017

$\begin{array}{llllll} & \text { Coefficient } & \text { Std. Error } & \text { t-ratio } & p \text {-value } \\ \text { const } & 0.0784630 & 0.625253 & 0.1255 & 0.9012 & \\ \text { l_GDP_pc_2017 } & 0.126781 & 0.0647137 & 1.959 & 0.0623\end{array} \quad *$

White's test for heteroskedasticity - Null hypothesis:

heteroskedasticity not present

Test statistic: $\mathrm{LM}=3.52181$ with p-value $=\mathrm{P}($ Chi-square(5) $>$

$3.52181)=0.620091$

EFP_pc - Ecological footprint per person
GDP pc - GDP per capita

SDI - Sustainable Development Index

Source: own processing in the Gretl program

Based on the coefficient of determination, $44.5 \%$ of the variability of the dependent variable was explained by the model. Neither collinearity nor heteroskedasticity (using White's test) was demonstrated. The independent variable GDP per capita was estimated with only a $90 \%$ probability and the independent variable SDI was estimated with a 95\% probability.

The resulting equation of the regression analysis of the three variables examined is as follows:



$\mathrm{n}=26$, R-squared $=0.445$ (standard errors in parentheses)

EFP_pc - Ecological footprint per person

GDP pc - GDP per capita

SDI - Sustainable Development Index

Based on the results of the above equation:

a) with an increase in GDP per capita of $1 \%$ ceteris paribus, we expect an increase in the ecological footprint per person by $0.13 \%$,

b) with an increase in the SDI index by $1 \%$ ceteris paribus, we expect a decrease in the ecological footprint per person by $0.25 \%$.

To better understand the results of the regression analysis, we present in Graphs 1a and 1b comparison of the relationship between GDP per capita and the SDI index for the creation of the ecological footprint per person individually.

Graph 1a: Relation of GDP per capita to the creation of the ecological footprint per capita in EU countries (except Luxembourg) in 2017



EFP_pc - Ecological footprint per person

GDP pc - GDP per capit

Source: own processing in the Gretl program

Graph 1b: Relationship of the SDI index to the creation of the ecological footprint per capita in EU countries (except Luxembourg) in 2017

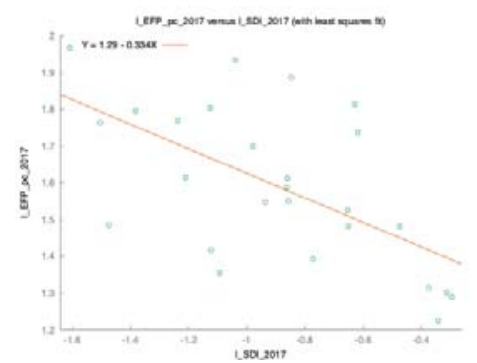

EFP_pc - Ecological footprint per person SDI - Sustainable Development Index Source: own processing in the Gretl program 
Graph 1a shows that as GDP per capita grows, so does the ecological footprint per capita, and Graph 1b shows that as SDI grows, so does the ecological footprint per capita.

The regression analysis examines the dependence of selected variables in EU countries (except Luxembourg) using crosssectional data for 2017. In this regard, it can be argued that the results of the regression analysis are limited mainly due to the examined short period (one year) and therefore we decided to supplement the analysis with another regression analysis through the use of panel data. In the given panel analysis, we examine the same sample of EU countries (except Luxembourg) in the period from 1995 to 2017.

To eliminate the apparent regression of the examined data (selected three variables), we chose as a solution the differentiation of variables that were logarithmic and for the elimination of the autocorrelation error, we chose a robust method of errors estimation. The results of the panel analysis are shown in Table 2.

Tab. 2: Panel regression analysis: Model 2

Model 2: Fixed-effects, using 572 observations

Included 26 cross-sectional units

Time-series length $=22$

Dependent variable: ld_EFP_pc

Robust (HAC) standard errors

$\begin{array}{lccccc} & \text { Coefficient } & \text { Std. Error } & \text { t-ratio } & p \text {-value } & \\ \text { const } & -0.0103490 & 0.00131792 & -7.853 & <0.0001 \\ * * * \\ \text { ld_HDP_pc } & 0.122043 & 0.0251128 & 4.860 & <0.0001 \\ \text { ld*** } \\ \text { ld_SDI } & -0.270451 & 0.0575351 & -4.701 & <0.0001\end{array} * * *$

LSDV R-squared $0.134991 \quad$ Within R-squared 0.115159

Test statistic: $\mathrm{F}(2,25)=36.5926$ with $\mathrm{p}$-value $=\mathrm{P}(\mathrm{F}(2,25)>$ 36.5926) = 3.74692e-08

Robust test for differing group intercepts - Null hypothesis: The groups have a common intercept

Test statistic: Welch $\mathrm{F}(25,196.4)=0.330904$ with $\mathrm{p}$-value $=$ $\mathrm{P}(\mathrm{F}(25,196.4)>0.330904)=0.999076$

EFP_pc - Ecological footprint per person

GDP pc - GDP per capita

SDI - Sustainable Development Index

Source: own processing in the Gretl program

Based on the coefficient of determination, $13.5 \%$ of the variability of the dependent variable was explained by the model. Nevertheless, the model is statistically significant and its results can be interpreted as relevant in relation to practice.

The resulting equation of the panel regression analysis of the three variables examined is:

^ld_EFP_pc $=-0.0103+0.122 *$ ld_GDP_pc $-0.270 *$ ld_SDI (0.00132) (0.0251) (0.0575)

$\mathrm{n}=572$, R-squared $=0.135$ (standard errors in parentheses)

EFP_pc - Ecological footprint per person

GDP pc - GDP per capita

SDI - Sustainable Development Index

Based on the results of the equation, we can state:

a) with an increase in GDP per capita of $1 \%$ ceteris paribus, we expect an increase in the ecological footprint per person by $0.12 \%$,

b) with an increase in the SDI index by $1 \%$ ceteris paribus, we expect a decrease in the ecological footprint per person by $0.27 \%$.

The results of the panel regression analysis (Table 2) show the same relationship between selected variables (as in the regression analysis of cross-sectional data - Table 1). This means that with an increase of GDP per capita ceteris paribus, we expect an increase in ecological footprint per capita, and with an increase of SDI index we expect a decrease in the ecological footprint per person.

The equation of the panel regression analysis shows that if GDP per capita increases by $1 \%$ ceteris paribus, we expect an increase in the ecological footprint per person by $0.12 \%$. This result confirms that economic growth based on the current linear model of the economy does not contribute to environmental sustainability. At the same time, the disturbance of biodiversity caused by human activity already poses a high threat today and will further distort and intensify socio-economic disproportions in the future. For these reasons, we consider it essential that the system be transformed into conditionality of sustainable development principles. It is also rather unlikely to expect national economies to approach the declared ambitious goals of the European Union, the United Nations or other national or supranational organizations by only self-reflection, when they do not change the conditions for assessing the results of the economic system - with aim to achieve sustainable production, consumption and the reduction of waste, unless compelled to do so by other legal procedures or means. The result of our regression analysis can also be verified in comparison with the conclusions of other significant and even more complex panel studies and evaluations (Mikkelson, 2019; Cibulka - Giljum, 2020; Holm - Englund, 2009; Chen - Chang, 2016; Mjid Zaman - Halim, 2018), where they examined the relationship between economic growth and the creation of an ecological footprint.

To compare the relationship between the development of society and the creation of the ecological footprint, we chose the SDI index as the second independent variable. The given index is a composite indicator. Although, it takes into account the indicator of ecological impact in its formula, it also contains other variables, and therefore we considered it interesting to examine such an indicator, which takes into account social progress in the intentions of planetary limits. The results of the equation show that with an increase in the SDI index by $1 \%$ ceteris paribus, a decrease in the ecological footprint per person by $0.27 \%$ is expected. The result of this quantitative analysis is also indirectly confirmed by the words of Kuznets who at the beginning of the 20th century expressed the idea that the real wealth of a nation cannot be assessed on the basis of achieved national income (the US Office of Foreign and Domestic Trade, 1934).

\section{Conclusion}

Based on the above, the current development, still most determined on the basis of "Profit only" is unsustainable for humanity in the long run. Unless the "most intelligent" creature on Earth chooses another path of development and evaluation of quality of life such as profit-based consumption its existence on planet Earth is endangered.

This was also verified by the results of the regression analysis, which shows the need for the necessary change of the current socio-economic system and reassessment of the overall value system, which under the influence of growing population and unchanged conditions will most likely lead to deeper depletion of natural resources. Taking into account the current changes in biodiversity, which have a global impact, we can conclude that with increasing numbers of people and increasing depletion of natural resources, more radical, stronger and more targeted decisions and changes are needed from international institutions, governments, businesses, but also individuals themselves. The absence of such activity could accelerate to the much more serious consequences we are already seeing today: water scarcity; floods; soil degradation; desertification; increasing migration due to resource shortages; deforestation; changes in individual ecosystems; generation of excessive waste and other extreme climate changes. 
It follows from the above that in order to minimize negative externalities, it is necessary to change the existing socioeconomic system. One of the solutions can be considered an efficient market system. As DeGrauwe said, the setting of market limits by governments, which will be reflected in higher prices of final products, may limit the creation of indirect costs for society (In Vaňo, 2019). BlackRock has announced that sustainability will be a key part of the investment portfolio allocation in the coming decades. It assumes that investment in sustainable development will no longer be relatively inefficient, as it expects an increase in regulations, sanctions, higher taxes and fees for emitters (Eltobgy - Walter, 2021). However, in terms of sustainable development, we consider it important to take into account the impacts of such decisions on the economy, society and the environment at the same time.

The results of the applied regression analysis confirmed to us that in order to achieve sustainable development, taking into account the ecological footprint in the processes of production and consumption is currently important and essential. As David Deutsch said we can achieve everything that does not deny the laws of nature - we just have to think up of how (In Pinker, 2019).

We consider global and uniform measurement of social development by another indicator than GDP (currently the most important indicator for measuring countries' economic growth) rather unrealistic in the near future - although there is growing interest and pressure from the professional public to create increasingly complex indicators to measure people's quality of life. On the other this confirms today's trend of taking interdisciplinarity into account in the evaluation of human phenomena. From this point of view, the application of the principles of the circular economy to the market economy can be a solution that would positively influence economic growth and at the same time transform the system of more sustainable production and consumption of natural resources. This solution would consist of efficient use of natural resources, minimization of the extraction of primary raw materials, reuse of waste, support the market for secondary raw materials and efficient recycling.

Many countries, especially the European ones, are gradually applying the principles of circularity to their economies. However, the transition from a (current) linear to a circular system is a complex process that can only be achieved by constant monitoring of its indicators, friendly government policies that take into account such a development and the responsible behaviour of businesses and people themselves. Last but not least, this process requires investment in science and research for the creation of environmentally friendly green technologies, but also in education, for the development of a global society that is aware of the interplay between man and nature.

\section{Literature:}

1. Eltobgy, M., Walter, J.: What gets measured gets managed: How sustainability reporting can help save the planet. World Economic Forum. 2021. from: https://www.wefor um.org/agenda/2021/01/what-gets-measured-gets-managed-howsustainability-reporting-can-help-build-a-better-

world?utm source=facebook\&utm medium=social scheduler\& utm_term=Governance+for+Sustainability\&utm_content $=26 / 01$ 2021+23:00\&fbclid=IwAR3QvJQj2psPpkHVzSI4pPXCsufUqP 7M3zM50sz7RJlyrGqcOHFU_IpLTgs

2. Global Footprint Network. About the Data. Global Footprint Network. 2021. from: https://data.footprintnetwork. org/?_ga=2.227669661.161140431.1614862349-

81793206.1614862349\#/abouttheData

3. Global Footprint Network. Ecological Footprint per Person. Global Footprint Network. 2020. from: https://data.footp rintnetwork.org/?_ga=2.182845990.1040798340.16113173831461245897.1609871502\#/
4. Holm, S., Englund, G.: Increased ecoefficiency and gross rebound effect: Evidence from USA and six European countries 1960-2002. Ecological Economics, 15 January 2009. Vol. 68(3), pp. 879-887. DOI: 10.1016/j.ecolecon.2008.07.006 5. Chen, S., Chang, H.: Factors that affect the ecological footprint depending on the different income levels. AIMS Energy. 2016. Vol. 4(4), pp. 557-573. DOI: 10.3934/energy. 2016.4.557

6. Kajikawa, Y.: Research core and framework of sustainability science. Sustain Sci (2008). 19 July 2008. pp. 215239. DOI 10.1007/s11625-008-0053-1

7. Lisý, J., et al.: Ekonomický rast a ekonomický cyklus. Teoretické a praktické problémy. Bratislava: lura Edition, 2011. s. 274. ISBN 9788080784058.

8. Lukáčik, M., Lukáčiková, A., Szomolányi, K.: Ekonometrické modelovanie v programoch EViews a Gretl. Bratislava: Ekonóm, 2011. pp. 330. ISBN 978-80- 225-3320-1. 9. Majid, M. R., Zaman, M., Halim, N.: Gis-Based Regression Analysis Of The Relationship Between Ecological Footprint And Economic Development Of Selected Countries. Planning Malaysia, Journal of the Malaysian Institute of Planners. 2018. Vol. 16. Issue 3. pp. 221-232. http://dx.doi.org/10.21837/p m.v16i7.513

10. Mikkelson, M. G.: Invisible Hand or Ecological Footprint? Comparing Social Versus Environmental Impacts of Recent Economic Growth. In: SAGE. 2019. Vol. 1(11). https://doi.org/10.1177/1086026619885111

11. OSN. Sustainable Development Report. Rankings. 2020. from: https://dashboards.sdgindex.org/rankings

12. Pinker, S.: Bud' svetlo. Obhajoba rozumu, vedy, humanizmu a pokroku. TATRAN 2019. Slovak edition, 2019. pp. 648. ISBN 9788022210195.

13. Sustainable Development Index. Methodology And Data. Sustaindevelopmentindex.org. 2021 a. from: https://www.sustai nabledevelopmentindex.org/methods

14. Sustainable Development Index. Sustaindevelopmen tindex.org. 2021. from: https://www.sustainabledevelopmentind ex.org/

15. Sustainable Development Index. Time Series (1990-2019). Sustaindevelopmentindex.org. 2021. from: https://www.sust ainabledevelopmentindex.org/time-series

16. Úrad pre zahraničný a domáci obchod USA. National Income, 1929 - 1932. 1934. from: https://fraser.stlouisfe d.org/title/971

17. Vaňo, V.: Ekonóm Paul DeGrauwe: Trhom sú ekologické náklady a nerovnost' ukadnuté, preto potrebujeme štát. Denník E. 2019. from: https://e.dennikn.sk/1624680/paul-degrauwe-zlondon-school-of-economics-len-trh-prinesie-blahobyt-ale-bezregulacie-znici-sam-seba/?fbclid=IwAR2V4pICONRkBE8OIU APVwenzSXm- tqRQ7BTj3XvcsBKwdi9jDtAOiOZr5Q 18. WB. GDP per capita (Current US \$). 2021. from: https://data.worldbank.org/indicator/NY.GDP.PCAP.CD 19. Zorkóciová, O., Palušková, H.: Environmental Economics Solutions for Plastic Waste Recycling. In Trends and Challenges in the European Business Environment: Trade, International Business and Tourism. International Scientific Conference. Trends and Challenges in the European Business Environment: Trade, International Business and Tourism: Proceedings of the 6th International Scientific Conference, October 17 - 18, 2019 (Mojmírovce, Slovak Republic). Bratislava: Vydavatel'stvo EKONÓM, 2019. ISBN 978-80-225-4646-1, 487-495 pp. CDROM.

20. Zorkóciová, O, Palušková, H.: Green Roof's Project: Environmental Solution for the People and the Company. In Management Mechanisms and Development Strategies of Economic Entities in Conditions of Institutional Transformations of the Global Environment. Scientific Council. Management Mechanisms and Development Strategies of Economic Entities in Conditions of Institutional Transformations of the Global Environment: Collective Monograph in 2 Vol. : Publication at the Meeting of the Scientific Council, 08th January 2019, No. 119, (Riga, Latvia). - Riga : Landmark SIA, 2019. ISBN 9789984-891-06-4, 59-75 pp. online.

21. Zábojník, S., Čiderová D., Krajčík D.: Competitiveness in International Business: Challenges for the EU Economies. Praha: 
Wolters Kluwer Czech Republic, 2020, 272 p. ISBN 978-80-

7676-006-6.

\section{Primary Paper Section: A}

Secondary Paper Section: AH, EH 